\title{
Monitoring of resistance spot welding process
}

\author{
Y. Sovetchenko ${ }^{1} \bullet$ D. Vdovychenko ${ }^{2} \bullet I_{\text {. Vdovychenko }}^{2} \bullet$ \\ Y. Chvertko ${ }^{2} \bullet$ I. Skachkov $\bullet$ M. Shevchenko ${ }^{2}$
}

Received: 3 September 2021 / Accepted: 25 October 2021

\begin{abstract}
Resistance spot welding is a process with high productivity and high level of automation. This rises a number of tasks related to development of quality evaluation and process monitoring systems operating in real-time mode which would allow to detect non-compliant joints during the process run of shortly after it is finished. The more complex task is to make such system as much universal as possible, consisting of relatively simple equipment and with a possibility of full automation of evaluation process. Research was focused on electrical welding parameters which determine the thermal cycle of the welding process as well as the state of metal in the welding zone and its plasticity. Experiments were performed for work pieces with different pre-welding state of surface. Developed method also allows to monitor the state of working surfaces of electrodes and to detect splashes with a relatively high accuracy.
\end{abstract}

Keywords: resistance spot welding; monitoring, splash; surface state; neural network.

\section{Introduction}

Resistance spot welding (RSW) is widely used in various fields of engineering: automotive, aircraft, electronics etc. This method is characterized by a very high degree of mechanization and automation - both contributing to its high productivity. RSW technology does not require welding materials (fluxes, filler wires, protective gases) and is its environment-friendly - an important indicator for any modern production seeking to meet the high requirements of environmental safety.

The main indicator of the quality of the welded joint produced by RSW is the strength of the spot, which is directly affected by its geometric parameters: size, shape and location. In turn, geometry of the welded spot depends on the course of the welding process and its deviations. On the other hand, welding technologies and equipment do not guarantee the complete absence of disturbances and fluctuations in electrical and mechanical characteristics of the equipment. In addition, the process

Y. Sovetchenko sovetchenko3098@gmail.com

$\triangle$ D. Vdovychenko d.m.vdovychenko@gmail.com

${ }^{1}$ Otto von Guericke University, Magdeburg, Germany

${ }^{2}$ Igor Sikorsky Kyiv Polytechnic Institute, Kyiv, Ukraine is affected by variations of the state of the surface of parts to be welded (when and how they were cleaned) as well as that of the working surface of the electrodes (while the difference between two consequent welding cycles may not be significant, with time these changes can lead to critical process deviations).

Research have proven that monitoring of electrical parameters of RSW process is an effective way to evaluate a possibility of defect formation and to detect critical systematic deviations of the welding process [1-3].

The objective of this work was to develop methods of evaluation of resistance spot welding process deviations which can possibly lead to defect formation with a possibility of easy automation of data analysis.

\section{Experiments details}

To solve the problem of monitoring the quality of welded joints, it was decided to investigate the influence of electrical parameters - current and voltage on the welding process. The studies were performed on samples of steel ST3 (group 1.1 ISO/TR 15608) $0.8 \mathrm{~mm}$ thick. Welding was performed on the MT-1215 machine.

Welding parameters for all groups of experiments remained unchanged [4]:

- welding current $10 \mathrm{kA}$; 
- compression force $2.3 \mathrm{kN}$;

- heating time $0.16 \mathrm{~s}$;

- forging time $1 \mathrm{~s}$;

- electrode diameter $5 \mathrm{~mm}$ at the beginning of experiments, reached $6 \mathrm{~mm}$ dia after welding series;

- cyclogram with constant compression force and one pulse of welding current.

Experiments were performed for different states of the surface of the samples:

- with a normal surface;

- with irregularities on the surface;

- with a polished surface;

- with an oily surface.

Measuring system included analog-digital converter E-140 (L-Card, Russia), voltage and current sensors and the system for primary data collecting and processing developed by the authors. In all the experiments the sampling frequency was set at $50 \mathrm{kHz}$ which is sufficient for signal recover for the welding methods investigated [5]. Rogowsky loop is a common current sensor for resistance welding equipment, but using it for measuring with high frequency leads to signal distortion in the periods when tyristors are switching on [1]. Thus the Rogowsky loop was replaced with an air current transformer. The voltage measurement was performed between two electrodeholders (the signal obtained included the welding zone and two electrodes) [2].

The measuring system was designed according to the following requirements:

- the equipment used should be uniform, with no special adjustments to use it for resistance spot welding process;

- no special training should be required to work with the system designed;

- the equipment should be able to work in conditions of resistance spot welding: short welding time, high energy applied to the parts to be welded, high level of electromagnetic disturbances, etc.;

- data processing should be considered due to huge amount of data recorded, including intermediate operations (integration, filtration, etc.).

Due to complex data processing needed it was decided to use digital system instead of analog one. Such system is easily operated and can be used to store huge data arrays and to process them rather quickly. Data recording was performed using L-Graph v.2.0 programme, data processing was performed with SciLab.

\section{Obtained results}

Data obtained via measuring current and voltage had to be processed to form arrays of values of effective power which could be adequately analyzed by means of artificial intellect. Neural networks are widely used for monitoring different welding processes [6] which makes it rational to apply the in this case as well. The main re- quirements to the data to be analyzed with neural networks are [7]:

- two data arrays should be developed: the training sequence used for network training and control one used to check the network operation;

- the training sequence should contain as many possible patterns of welded spots' formation as possible;

- data placement in the training sequence should not be aligned with any kind of relationship;

- data in training sequence should be normalized to avoid changes of welding parameters to effect the classification; the information should be taken from the signal form, not its value [8].

According to requirements listed it was decided to used integrated by the time equal to half of main power period values of effective power.

On graphs of effective power for each sample (Fig. 1) two zones can be identified.

Zone I indicates the initial stage of the process, which depends on a large number of technical, technological and organizational factors (preparation of surfaces of parts and working surfaces of electrodes; size, shape and chemical composition of parts and electrodes, welding parameters, etc.). Zone II indicates a stable process, the descending nature of which is due to the fact that the system "machine-welding zone" is not in a static state (molten zone growth; changes in size due to plastic deformation; dilatometric effect; changes in shape and size of contact surface between the electrode and the part). In research for easier automation of data processing the threshold between these zones was isentified as the peak value on the graph.

It was determined that the curve slopes in zone II is similar for data related to experiments within the same group of samples, but may differ significantly if during welding splashing takes place or in case of comparison of samples from different groups. This data can be used for operational control by calculating the angle during welding and adjusting the welding current if needed.

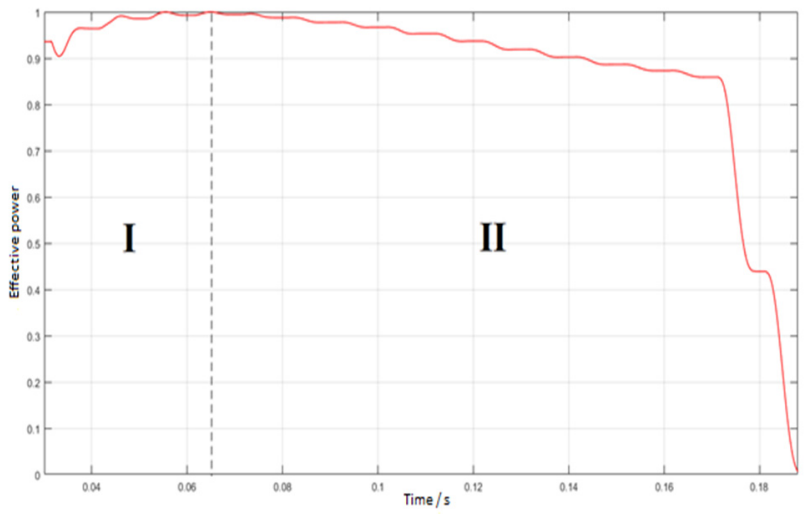

Fig. 1. Typical graph of effective power for a single resistance spot welding process 
In general, the state of the surface affects the formation of the primary contact resistance between the parts to be welded in the zone, where further melting should begin. Additional roughness reduces the total contact area, and the oil creates areas with limited conductivity. It should be noted that the oil when heated can lead to the introduction into the welding zone of organic compounds, which, in turn, are known to be sources of hydrogen.

\section{Discussion}

\section{Effect of surface state}

From the graphs (Fig. 2) it is noticeable that in general, in the absence of other process failures (e.g., splashes), the nature of the curves is similar. Significant differences are observed in the initial stage of the processwhere the formation of the primary contact takes place. Towards the end of the heating, the angle of inclination of the curves begins to differ, most likely, due to differences in the resistance of the welding zone. Although the identification of the condition of the surfaces of the parts before welding cannot be used to adjust the mode in real time, as far as we cannot stop the process and clean the part, it can provide statistical information and help to identify systematic violations.

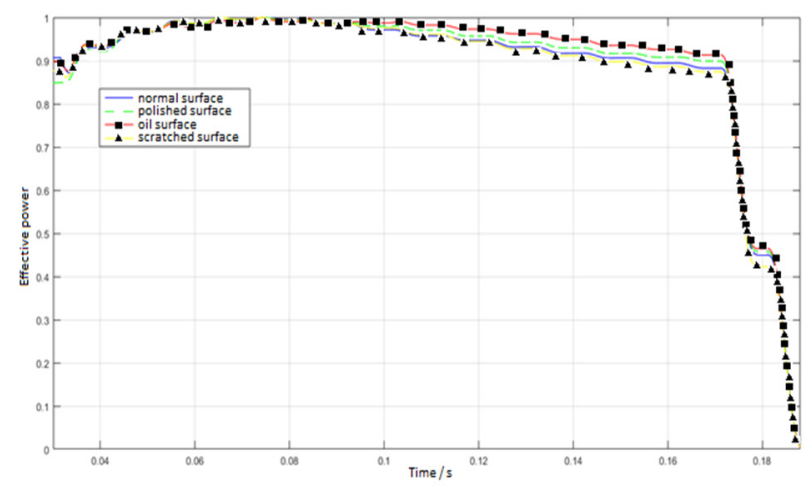

Fig. 2. Typical graphs of effective power for different groups of samples

\section{Effect of working surface of electrodes}

The working surface of the electrodes plays an important role in resistance spot welding. Over time, it changes in shape, size and condition (the presence of solid inclusions with limited conductivity).

The graphs (Fig. 3) show that the nature of the curve without additional failures (splashes, overvoltage) remains unchanged. In fact, the curve gradually shifts upward, each time slightly changing the angle of inclination. This information is suitable for tracking the degree of wear of the working surface of the electrode. Sharp changes in the angle of the curve during subsequent welding cycles can be a signal for the need to tend to the working surface of the electrodes.

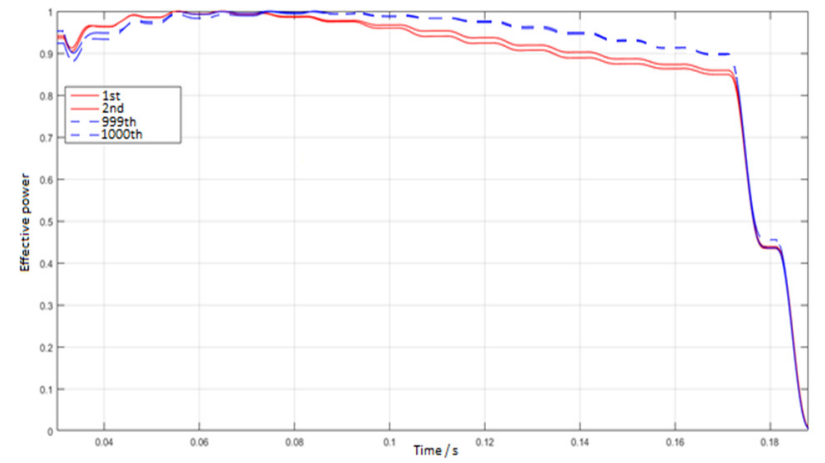

Fig. 3. Effective power graphs for $1^{\text {st }}, 2^{\text {nd }}, 999^{\text {th }}$ and $1000^{\text {th }}$ welding cycles

\section{Effect of expusions}

Presence of splashes, even if they weren't accompanied with sparks ejection, can also be determined on the effective power graphs (Fig. 4). When comparing the curves of welding processes without and with splashes, the differences are clearly visible making it possible to identify this defect by monitoring electrical parameters.

If the splash is initial, then the shape of the curves will change in the initial stage of the process. In this case it is relatively hard to distinguish the splash from other factors affecting the initial contact formation. However, clear identification is possible for the splashes on later process stages. Actually, the final internal splash occurs due to the rupture of the sealing ring, which, in turn, leads to an abrupt change in the resistance of the welding zone. The splash reduces the amount of molten metal in the welding zone and sometimes partially shunts the parts with crystallized metal, which leaked behind the sealing ring - thus reducing the current.

On the graph, the splashes appear in the form of local subsidence of the curve closer to the end of heating, i.e. to a sharp increase in the inclination angle. Almost parallel downward displacement of the end section of the curve at the stage of completion of heating is due to the difference between the electrical resistance of the spot after the splash and the spot formed without splash.

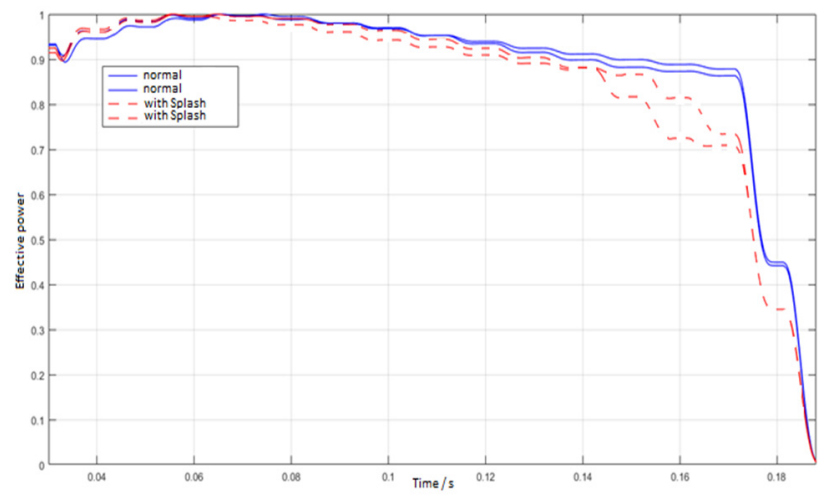

Fig. 4. Graphs of effective power with and without splashes 


\section{Application of artificial neural networks for splash detection}

Neural networks can be used to find and analyze implicit relations between data arrays. In our case the main task of network was to classify data according to disturbances in welding process despite the state of the samples' surface and to divide them into two classes: with and without splashes.

For data processing the Feedforward neural network was used. It consists of an input layer, 20 hidden layers, and an output layer (a typical shallow neural network) One-dimensional arrays with effective power function values for splash-free samples were fed to the Neural Network as a training sequence. This array was then used as the input and output so that the neural network learned to recognize welding sequences without splashes and, as a result, to distinguish them from the ones with splashes using the root mean square error.

The root mean square error is the mean square difference between the results and the goals. The lower the values, the more similar the effective power values are, indicating that these points are splash-free.

After training the neural network data from 38 experiments were selectively tested.

For samples without splashes, the standard error did not exceed $7 \cdot 10^{-12}$ while the mean square error for samples with splashes in most cases exceeded $1 \cdot 10^{-11}$.

The neural network has successfully detected samples with splashes using the root mean square error in all cases except one. The sample with unidentified splash (number 65) did not show an splash and had the standard error $6.72 \cdot 10^{-12}$. Authors believe this is due to the fact that the splash occurred on the final semi-period of current flowing through the parts - the curve except a few final values does not differ from the ones without splashes. In Fig. 5. it is noticable well that the curve with (65th sample)

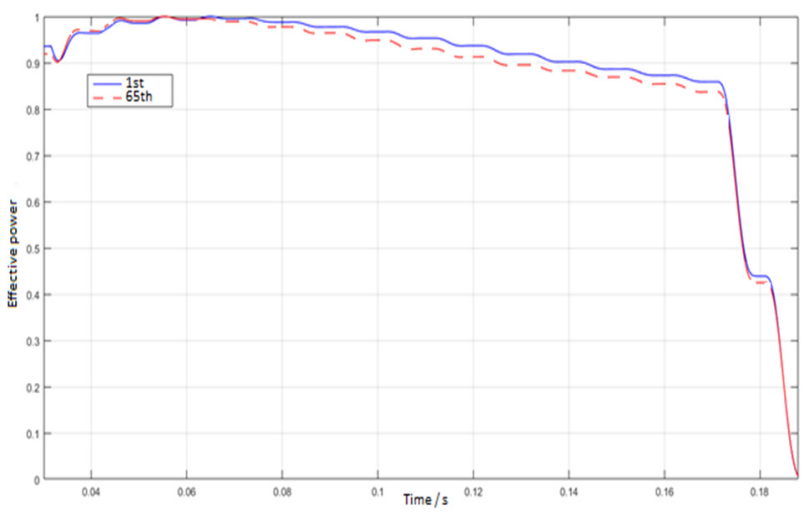

Fig. 5. Graphs of effective power of $1^{\text {st }}$ (without splash) and $65^{\text {th }}$ (with splash) samples

and without (1st sample) splash are very similar. It is therefore not surprising that the neural network did not distinguish them.

\section{Conclusions}

1. Effect of surface state of parts to be welded on deviations of resistance spot welding process was studied; experiments were performed on samples with different surface roughness as well as on those with oily surface. Effective power was calculated and used as a parameter to analyze the welding process.

2. It was determined that the slope of effective power curves not only depict the differences on the initial stage of heating, but may as well be used to detect splashes and to monitor the electrode working surface degradation.

3. Artificial neural network was trained to distinguish welding sequences with splashes from those without ones. Selective check has proven the neural network efficiency.

\section{References}

[1] Kang Zhou, Ping Yao, "Overview of recent advances of process analysis and quality control in resistance spot welding", Mechanical Systems and Signal Processing, Vol. 124, pp. 170-198, 2019. https://doi.org/10.1016/j.ymssp.2019.01.041

[2] Hongjie Zhang et al., "A new method for nondestructive quality evaluation of the resistance spot welding based on the radar chart method and the decision tree classifier", The International Journal of Advanced Manufacturing Technology, No. 78, pp. 841-851, 2014. https://doi.org/10.1007/s00170-014-6654-1

[3] C.D.E. Summerville et al., "Process Monitoring of Resistance Spot Welding Using the Dynamic Resistance Signature", Welding Journal, pp. 403-412, 2017. [Online]. Available: https://s3.amazonaws.com/WJ-www.aws.org/supplement/WJ_2017_11_s403.pdf

[4] DVS: "Widerstandspunktschweißen von Stählen bis $3 \mathrm{~mm}$ Einzeldicke-Grundlagen, Vorbereitung und Durchführung”, DVSMerkblatt 2902-4, 2001. [Online]. Available: https://www.dvs-media.eu/media/pdf/44967997.pdf

[5] Ye. Chvertko, A. Pirumov and M. Shevchenko, "Monitoring of the process of Flash-Butt Welding", Soldagem \& Inspeção, No. 1, Vol. 18, pp. 31-38, 2013. https://doi.org/10.1590/S0104-92242013000100005

[6] Ie. Chvertko, A. Pirumov and M. Shevchenko, "Monitoring of welding processes with application of artificial neuralnetworks", Bulletin of the NYUU “KPI”, No. 2, pp. 88-93, 2014.

[7] S. Osovskiy, Neural networks for information processing, Moscow, Russia: Finance and statistics, 2002.

[8] S. Khaikin, Neural networks, Kharkov, Ukraine: Viliams, 2006. 


\section{Мониторинг процесса контактной точечной сварки}

\section{Я. Советченко, Д. Вдовиченко, И. Вдовиченко, Е. Чвертко, И. Скачков, Н. Шевченко}

Аннотация. Контактное точечная сварка является высокопроизводительным процессом с высоким уровнем автоматизации. Поэтому актуальными оказываются задачи, связанные с разработкой методов оценки качества процесса и его мониторинга. При этом система должна работать в режиме реального времени, что позволит идентифицировать соединения, которые не соответствуют критериям приемки, в течение процесса сварки или сразу после его завериения. Более сложной оказывается задача универсализации таких систем, в том числе за счет использования простого оборудования с возможностью полной автоматизации процесса мониторинга и оценки. В исследовании рассматривали электрические параметры режима сварки, которые определяют термический цикл прочесса и состояние металла в зоне сварки и характеристики его пластичности. Эксперименты были проведены для образцов с разным качеством подготовки поверхностей перед сваркой. Разработанный метод позволяет также отслеживать состояние рабочих поверхностей электродов и определять выплески с высокой точностью.

Ключевые слова: контактное точечная сварка, мониторинг, выплеск, состояние поверхности, нейронная сеть.

\section{Моніторинг процесу контактного точкового зварювання}

\section{Ярослав Советченко, Дмитро Вдовиченко, Іван Вдовиченко, Свгенія Чвертко, Ігор Скачков, Микола Шевченко}

Анотація. Контактне точкове зварювання є високопродуктивним процесом із високим рівнем автоматизації. Через иее актуальними виявляються задачі, пов'язані з розробкою методів оцінювання якості процесу та його моніторингу. При цьому система має прачювати в режимі реального часу, щьо дозволить ідентифікувати з'єднання, що не відповідають критеріям прийомки, протягом прочесу зварювання або одразу після його завершення. Більш складною виявлясться задача універсалізації таких систем, зокрема за рахунок використання простого обладнання з можливістю повної автоматизації прочесу моніторингу та оиінювання. У дослідженні розглядали електричні параметри режиму зварювання, які визначають термічний цикл процесу та стан металу в зоні зварювання й характеристики його пластичності. Експерименти були проведені для зразків з різною якістю підготовки поверхонь перед зварюванням. Розроблений метод дозволяє також відслідковувати стан робочих поверхонь електродів та визначати виплески з високою точністю.

Ключові слова: контактне точкове зварювання; моніторинг; виплеск; стан поверхні; нейронна мережа. 